\title{
KNOWLEDGE, ATTITUDE, AND PRACTICE OF DENTISTS TOWARDS CORONAVIRUS DISEASE (COVID-19): A CROSS-SECTIONAL STUDY
}

\author{
Randa Youssef Abd Al Gawad * and Sara Ahmed Mahmoud *
}

\begin{abstract}
Objective: To assess the knowledge, attitude, and practice of dentists towards coronavirus disease (Covid-19) in Egypt.

Material and methods: A total of 374 Egyptian dentists participated in this cross-sectional survey following the outbreak of COVID-19 in Egypt. A validated well-constructed online questionnaire consisting of four sections (32 questions) was distributed through different social networking websites to measure the knowledge, attitude, and practice of Egyptian dentists regarding the pandemic.
\end{abstract}

Results: Regarding the knowledge, a significantly higher percentage of dentists thought that the infection was caused by coronavirus (95.0\%). Considering attitude, dentists agreed that COVID-19 transmission can be prevented by using the WHO standard isolation precautions $(43.5 \%)$, and their practice was with a higher percentage of respondents deferred dental treatment of suspicious patients $(83.77 \%)$, did not think surgical mask was sufficient to prevent cross-infection $(80.63 \%)$, and favored the wear of N-95 mask $(84.55 \%)$.

Conclusion: Egyptian dentists were aware of the COVID-19 virus, mode of transmission, and infection control precautions in the dental clinic, and showed a positive attitude towards the importance of education about COVID-19.

KEYWORDS: Coronavirus, COVID-19, Dentists, Egypt, KAP

\section{INTRODUCTION}

A novel strain of coronavirus was detected in a seafood market in Wuhan, China. ${ }^{[3-4]}$ This virus is the seventh member of the family coronaviruses that infect humans causing viral pneumonia with a high fatality rate. ${ }^{[1,2]}$ On February 11, 2020, WHO used the term (COVID-19) to describe the novel out-breaking coronavirus. ${ }^{[5]}$

Severe Acute Respiratory Syndrome Coronavirus-2 (SARS-CoV-2) is easily transmitted from human to human through airborne particles, surface particles, hands, saliva, nasal droplets, and

\footnotetext{
* Associate Professor of Pediatric Dentistry \& Dental Public Health- Faculty of Dentistry- Cairo University.
} 
close contact with infected individuals. ${ }^{[6,7]}$ The average incubation period of COVID-19 ranges from 2 to 14 days after exposure. ${ }^{[8,9]}$

The most observed clinical manifestations of an infected individual are high fever, fatigue, dry cough, myalgias, dyspnea; more ever other symptoms can be presented like headache, sore throat, rhinorrhea, and gastrointestinal symptoms. ${ }^{[10,11]}$

Dentists are most frequently facing different pathogenic viruses and bacteria that attack the oral cavity and respiratory tract ${ }^{[3]}$. Dental care delivery procedures carry a high risk of COVID-19 transmission, due to the nature of direct and close contact with infected cases or carriers. ${ }^{[12]}$

Dealing with the patient's body fluids (saliva and blood), dental instruments' manipulation, together with the presence of dental aerosols and droplets together with the absence of high standard infection control protocol; all increase the risk of cross-infection and spread of the pandemic ${ }^{[12-14]}$. Therefore, dentists should be realizing the importance to follow practical guidelines recommended for dentists by the Centers for Disease Control and Prevention (CDC), the American Dental Association (ADA), and the World Health Organization (WHO) to minimize the spread of COVID-19 infection and to ensure the safety of both patients and dental healthcare professionals. ${ }^{[15-18]}$ These recommendations (Deferring elective dental treatments for at least 2-3 weeks for suspected cases and following strict infection control guidelines) are adopted by Egyptian governmental authorities and the Ministry of Health and Population (MOHP).

The challenging situation is that dentists are responsible for delivering good quality emergency dental care despite the knowledge gap about the outbreaking, rapidly spread, and severe COVID-19 pandemic ${ }^{[19]}$ So, their knowledge, attitude, and practice (KAP) towards COVID-19 infection are crucial. ${ }^{[20]}$ Thus, the present study was conducted to assess the knowledge, attitude, and practice
(KAP) of dentists towards COVID-19 disease, to facilitate outbreak management of the pandemic in Egypt, and to increase dentists' role in detecting and reporting Coronavirus cases at this critical moment.

\section{Material and Methods}

\section{Study design:}

This is a cross-sectional survey conducted during the outbreak of COVID-19 and quarantine in Egypt, using an online survey questionnaire (available from May 2020 to June 2020). The Questionnaire was available online till the sample size was achieved.

The research protocol was approved by the Committee of Ethics, Faculty of Dentistry, Cairo University, (ID: 40720).

\section{Participants:}

The target participants were enrolled in this study according to the following eligibility criteria:

\section{Inclusion criteria:}

- Egyptian Dentists.

- Different specialties in dentistry.

- Working in both Governmental and lor Private sectors

- Approved electronic informed consent before participating in this survey.

\section{Exclusion criteria:}

- Non-practicing dentist during quarantine.

- Participants who did not complete the questionnaire.

\section{Sample size calculation:}

A power analysis was designed to have adequate power to apply a statistical test of the research question (KAP of dentists towards COVID-19 disease). According to the results of Asaad et al., $2019^{[21]}$ in which the prevalence of Coronavirus knowledge among participants was (42\%) and 
by adopting a confidence interval of $(95 \%)$ and a margin of error of $(5 \%)$ with finite population correction; the predicted sample size was found to be a total of $(n=374)$ cases. Sample size calculation was performed using Epi info for windows version $7.2^{2}$.

\section{Questionnaire design:}

A validated well-constructed, online, electronic questionnaire (Appendix I), based on previously published studies ${ }^{[1,21,22]}$, to assess KAP of dentists towards COVID-19 disease was designed using Google Forms.

The questionnaire consisted of four sections (32 questions), an introductory paragraph explaining the aim of the survey, explanatory instructions to complete the questionnaire, and an electronic informed consent approval before subsequent participation.

Section 1: had eight items that explored the demographic and professional background of participants (age, gender, specialty, nature of practice, existence of other family healthcare Worker (HCW), relatives who suffered from COVID-19 \& source of COVID-19 knowledge).

Section 2: composed of four items and was designed to evaluate dentists' knowledge about COVID-19 (causes, sources of transmission, mortality, \& preventive measures) at three possible levels (yes, no, I do not know).

Section 3: consisted of nine questions to evaluate dentists' attitudes towards COVID-19 based on a 5-point Likert scale (1: strongly agree, 2: agree, 3: neutral, 4: disagree \& 5: strongly disagree).

Section 4: was designed to obtain information about dentists' practice modifications according to the CDC $2020^{[23]}$ and ADA 2020 practice guidelines ${ }^{[24]}$ to counter the COVID-19 outbreak (11 questions) at three possible levels (yes, no, I do not know).

\section{Questionnaire distribution and data collection:}

The online questionnaire link was distributed through different social networking websites (Facebook Groups and Messenger, Social pages, and WhatsApp), and e-mails were sent to dentists.

Data collection was terminated during the COVID-19 pandemic outbreak. All responded questionnaires were collected electronically via Google Form and were subjected to statistical analysis.

\section{Bias:}

- The introductory paragraph explaining the aim of the survey, as well as, instructions to complete the questionnaire provided a standardized protocol to participants to avoid Performance bias.

- The high-quality questionnaire with closeended questions allowed sufficient time for adequate information recall thus minimizing information bias and recall bias.

- Finally, the used Google forms provided accurate collection, recording, and reporting of the data, thus decreasing detection and reporting bias.

\section{Statistical analysis:}

Fisher's exact test was used to analyze categorical data (frequencies and percentages). The level of significance was set at $p \leq 0.05$ and was corrected for multiple comparisons using Bonferroni correction. Statistical analysis was processed with $\mathrm{R}$ statistical analysis software version 4.0.2 for Windows ( $R$ Core Team, 2020. R Foundation for Statistical Computing, Austria). ${ }^{[25]}$

\section{RESULTS}

The questionnaire was sent electronically to 8366 dentists and was answered by 382 respondents, with a response rate of $0.0457 \%$. 


\section{A-Demographic and general data, (Q1-8)}

Demographic and general data of respondents are illustrated in Table (I).

Significantly higher percentages of respondents were above 30 years of age [245 $(64.1 \%),(p<0.001)]$, females [245, $(64.1 \%), p<0.001]$, working at both public and private sectors [153 (40.1\%), $p=0.013$ ], having HCWs relatives [267 (69.9\%), $p<0.001$ ], and thought that their level of knowledge of COVID-19 was sufficient [226 (59.2\%), $p<0.001]$.

Respondents were nearly divided between having [182 (47.6\%)] and not having [200 (52.4\%)] relatives who had suffered COVID-19 infection (no-significant difference, $p=0.357$ ). Regarding the source of COVID-19 knowledge, 309 (80.9\%) chose to depend on more than one source of knowledge, $p<0.001$.

\section{B) Knowledge of dentists about COVID-19, (Q1-4)}

Regarding the knowledge of dentists about COVID-19, a significantly higher percentage of dentists thought that the infection was caused by Coronavirus [363 (95.0\%)], that it could be fatal [381 (99.7\%)], that it could be transmitted easily [369 (96.6\%)], and that its transmission could be prevented by washing hands with soap [374 (97.9\%)], $p<0.001$, (Table II).

\section{C) Attitude of dentists about COVID-19, (Q1-9)}

A significantly higher percentage of respondents, strongly disagreed that COVID-19 was not currently a serious public health issue [214 (56.0\%)], disagreed that COVID-19 symptoms often resolved with time and did not require any special treatment [126 (33.0\%)], and agreed to refuse to work in a hospital where infected patients were treated [120 $(31.4 \%)]$
Also, a significantly higher percentage of respondents agreed that COVID-19 transmission can be prevented by using WHO standard isolation precautions [166 (43.5\%)], and felt neutral regarding the ability of the governmental institutions of controlling the pandemic [140 (36.6\%)], $p<0.001$.

In addition, it was found that most of the respondents strongly agreed to the necessity of educating people about COVID-19 [341 (89.3\%)], that HCWs must acknowledge themselves with all the information about the virus [348 (91.1\%)], and that they would not work in a hospital without a clear COVID-19 infection control isolation policy [256 (67.0\%)], $p<0.001$. As shown in (Table III).

\section{D-Practice of dentists about COVID-19, (Q1-11):}

There was a non-significant difference between answers to the questions regarding taking every patient's body temperature before performing the dental treatment, $(p=0.838)$, wearing an N-95 mask while treating patients, $(p=0.052)$, and following infection control universal precautions, $(p=0.145)$ with nearly equal percentages of dentists choosing either "yes" or "no".

A significantly higher percentage of respondents deferred dental treatment of suspicious patients [320 (83.77\%)], did not think surgical mask was sufficient to prevent cross-infection [308 (80.63\%)], favored the wear of N-95 mask [323 (84.55\%)], and did not use rubber dam for isolation [235 (61.52\%)].

Also, a significantly higher percentage used high volume section for every patient [249 (65.18\%)], did not instruct each patient to use mouthwash [227 (59.42\%)], washed their hands with soap and water/use sanitizer before and after treatment [370 $(96.86 \%)]$, and were aware of the suspected cases referral authority $[291(76.18 \%)], p<0.001$. As illustrated in Table IX. 
TABLE (I): Frequencies (n) and percentages (\%) of answers to demographic questions

\begin{tabular}{|c|c|c|c|c|}
\hline \multicolumn{2}{|c|}{ Demographic questions } & $\mathrm{n}$ & $\%$ & $p$-value \\
\hline \multirow{2}{*}{ 1-Age } & $<30$ & 137 & $35.9 \%$ & \multirow{2}{*}{$<0.001 *$} \\
\hline & $>\mathbf{3 0}$ & 245 & $64.1 \%$ & \\
\hline \multirow{2}{*}{ 2-Gender } & Male & 137 & $35.9 \%$ & \multirow{2}{*}{$<0.001 *$} \\
\hline & Female & 245 & $64.1 \%$ & \\
\hline \multirow{2}{*}{ 3-Specilaity } & Specialist & 306 & $80.1 \%$ & \multirow{2}{*}{$<0.001 *$} \\
\hline & Not a specialist & 76 & $19.9 \%$ & \\
\hline \multirow{3}{*}{ 4-Nature of practice } & Private sector & $122^{\mathrm{B}}$ & $31.9 \%$ & \multirow{3}{*}{$0.013 *$} \\
\hline & $\begin{array}{c}\text { Governmental sector (MOHP } \\
\text { \& University) }\end{array}$ & $107^{\mathrm{B}}$ & $28.0 \%$ & \\
\hline & Both & $153^{\mathrm{A}}$ & $40.1 \%$ & \\
\hline \multirow{2}{*}{$\begin{array}{l}\text { 5-Do you have other Healthcare provider } \\
\text { (s) in the family? }\end{array}$} & Yes & 267 & $69.9 \%$ & \multirow{2}{*}{$<0.001 *$} \\
\hline & No & 115 & $30.1 \%$ & \\
\hline \multirow{2}{*}{$\begin{array}{l}\text { 6-Do you have any relatives or friends } \\
\text { who suffered from COVID-19? }\end{array}$} & Yes & 182 & $47.6 \%$ & \multirow{2}{*}{$0.357 \mathrm{~ns}$} \\
\hline & No & 200 & $52.4 \%$ & \\
\hline \multirow{2}{*}{$\begin{array}{l}\text { 7-From your point of view, do you have } \\
\text { sufficient knowledge about COVID-19? }\end{array}$} & Yes & 226 & $59.2 \%$ & \multirow{2}{*}{$<0.001 *$} \\
\hline & No & 156 & $40.8 \%$ & \\
\hline \multirow{6}{*}{$\begin{array}{l}\text { 8-What is your source of knowledge } \\
\text { about COVID-19? }\end{array}$} & WHO website & $34^{\mathrm{A}}$ & $8.9 \%$ & \multirow{6}{*}{$<0.001 *$} \\
\hline & MOHP website & $10^{\mathrm{BC}}$ & $2.6 \%$ & \\
\hline & TV or radio & $5^{\mathrm{BD}}$ & $1.3 \%$ & \\
\hline & Posters and brochures & $2^{\mathrm{D}}$ & $0.5 \%$ & \\
\hline & Social media & $22^{\mathrm{AC}}$ & $5.8 \%$ & \\
\hline & More than one source of data & $309^{\mathrm{E}}$ & $80.9 \%$ & \\
\hline
\end{tabular}

Different superscript letters indicate a statistically significant difference within the same question*; significant $(p \leq 0.05) n s$; non-significant $(p>0.05)$

TABLE (II): Frequencies (n) and percentages (\%) of responses to knowledge questions

\begin{tabular}{|c|c|c|c|c|}
\hline \multicolumn{2}{|c|}{ Knowledge of dentists about COVID-19 } & $\mathrm{n}$ & $\%$ & $p$-value \\
\hline \multirow{3}{*}{$\begin{array}{l}\text { 1- Is COVID-19 caused by } \\
\text { coronavirus? }\end{array}$} & Yes & $363^{\mathrm{A}}$ & $95.0 \%$ & \multirow{3}{*}{$<0.001 *$} \\
\hline & No & $8^{\mathrm{B}}$ & $2.1 \%$ & \\
\hline & I don't know & $11^{\mathrm{B}}$ & $2.9 \%$ & \\
\hline \multirow{3}{*}{$\begin{array}{l}\text { 2- Could COVID-19 be fatal in } \\
\text { some cases? }\end{array}$} & Yes & 381 & 99.7 & \multirow{3}{*}{$<0.001 *$} \\
\hline & No & 0 & $0 \%$ & \\
\hline & I don't know & 1 & $0.3 \%$ & \\
\hline \multirow{3}{*}{$\begin{array}{l}\text { 3- Can COVID-19 be transmitted } \\
\text { easily from person to person? }\end{array}$} & Yes & $369^{\mathrm{A}}$ & $96.6 \%$ & \multirow{3}{*}{$<0.001 *$} \\
\hline & No & $4^{\mathrm{B}}$ & $1.0 \%$ & \\
\hline & I don't know & $9^{\mathrm{B}}$ & $2.4 \%$ & \\
\hline \multirow{3}{*}{$\begin{array}{l}\text { 4- Can washing hands with soap } \\
\text { and water help in the prevention of } \\
\text { disease transmission? }\end{array}$} & Yes & $374^{\mathrm{A}}$ & $97.9 \%$ & \multirow{3}{*}{$<0.001 *$} \\
\hline & No & $3^{\mathrm{B}}$ & $0.8 \%$ & \\
\hline & I don't know & $5^{\mathrm{B}}$ & $1.3 \%$ & \\
\hline
\end{tabular}

Different superscript letters indicate a statistically significant difference within the same question*; significant (p $\leq 0.05)$ $n s$; non-significant ( $p>0.05)$ 
TABLE (III): Frequencies (n) and percentages (\%) of responses to attitude questions

\begin{tabular}{|c|c|c|c|c|}
\hline \multicolumn{2}{|c|}{ Attitude of dentists about COVID-19 } & $\mathrm{n}$ & $\%$ & $p$-value \\
\hline \multirow{5}{*}{$\begin{array}{l}\text { 1- I believe COVID-19 is not cur- } \\
\text { rently a serious public health } \\
\text { issue }\end{array}$} & Strongly agree & $18^{\mathrm{A}}$ & $4.7 \%$ & \multirow{5}{*}{$<0.001 *$} \\
\hline & Agree & $16^{\mathrm{A}}$ & $4.2 \%$ & \\
\hline & Neutral & $16^{\mathrm{A}}$ & $4.2 \%$ & \\
\hline & Disagree & $118^{\mathrm{B}}$ & $30.9 \%$ & \\
\hline & Strongly disagree & $214^{\mathrm{C}}$ & $56.0 \%$ & \\
\hline \multirow{5}{*}{$\begin{array}{l}\text { 2-COVID-19 symptoms often } \\
\text { resolve with time and do not } \\
\text { require any special treatment }\end{array}$} & Strongly agree & $16^{\mathrm{A}}$ & $4.2 \%$ & \multirow{5}{*}{$<0.001 *$} \\
\hline & Agree & $102^{\mathrm{BC}}$ & $26.7 \%$ & \\
\hline & Neutral & $89^{\mathrm{B}}$ & $23.3 \%$ & \\
\hline & Disagree & $126^{\mathrm{C}}$ & $33.0 \%$ & \\
\hline & Strongly disagree & $49^{\mathrm{D}}$ & $12.8 \%$ & \\
\hline \multirow{5}{*}{$\begin{array}{l}\text { 3-Educating people about CO- } \\
\text { VID-19 is important to prevent } \\
\text { the spread of the disease }\end{array}$} & Strongly agree & $341^{\mathrm{A}}$ & $89.3 \%$ & \multirow{5}{*}{$<0.001^{*}$} \\
\hline & Agree & $38^{\mathrm{B}}$ & $9.9 \%$ & \\
\hline & Neutral & $1^{\mathrm{C}}$ & $0.3 \%$ & \\
\hline & Disagree & 0 & $0 \%$ & \\
\hline & Strongly disagree & $2^{\mathrm{C}}$ & $0.5 \%$ & \\
\hline \multirow{5}{*}{$\begin{array}{l}\text { 4-You worry about one of your } \\
\text { family members can get the } \\
\text { infection }\end{array}$} & Strongly agree & $291^{\mathrm{A}}$ & $76.2 \%$ & \multirow{5}{*}{$<0.001 *$} \\
\hline & Agree & $78^{\mathrm{B}}$ & $20.4 \%$ & \\
\hline & Neutral & $9^{c}$ & $2.4 \%$ & \\
\hline & Disagree & $2^{\mathrm{C}}$ & $0.5 \%$ & \\
\hline & Strongly disagree & $2^{\mathrm{C}}$ & $0.5 \%$ & \\
\hline \multirow{5}{*}{$\begin{array}{l}\text { 5-Healthcare workers must ac- } \\
\text { knowledge themselves with all } \\
\text { the information about the virus }\end{array}$} & Strongly agree & $348^{\mathrm{A}}$ & 91.1 & \multirow{5}{*}{$<0.001 *$} \\
\hline & Agree & $33^{\mathrm{B}}$ & 8.6 & \\
\hline & Neutral & $1^{\mathrm{C}}$ & 0.3 & \\
\hline & Disagree & 0 & $0 \%$ & \\
\hline & Strongly disagree & 0 & $0 \%$ & \\
\hline \multirow{5}{*}{$\begin{array}{l}\text { 6-Transmission of COVID-19 can } \\
\text { be prevented by using standard } \\
\text { isolation precautions recom- } \\
\text { mended by the CDC \& WHO }\end{array}$} & Strongly agree & $147^{\mathrm{A}}$ & $38.5 \%$ & \multirow{5}{*}{$<0.001 *$} \\
\hline & Agree & $166^{\mathrm{A}}$ & $43.5 \%$ & \\
\hline & Neutral & $59^{\mathrm{B}}$ & $15.4 \%$ & \\
\hline & Disagree & $9^{\mathrm{C}}$ & $2.4 \%$ & \\
\hline & Strongly disagree & $1^{\mathrm{D}}$ & $0.3 \%$ & \\
\hline \multirow{5}{*}{$\begin{array}{l}\text { 7-I will not do my clinical duties } \\
\text { in a hospital where COVID-19 } \\
\text { patients are treated }\end{array}$} & Strongly agree & $53^{\mathrm{AB}}$ & $13.9 \%$ & \multirow{5}{*}{$<0.001 *$} \\
\hline & Agree & $74^{\mathrm{AC}}$ & $19.4 \%$ & \\
\hline & Neutral & $95^{\mathrm{CD}}$ & $24.9 \%$ & \\
\hline & Disagree & $120^{\mathrm{D}}$ & $31.4 \%$ & \\
\hline & Strongly disagree & $40^{\mathrm{B}}$ & $10.5 \%$ & \\
\hline
\end{tabular}




\begin{tabular}{|c|c|c|c|}
\hline \multicolumn{2}{|c|}{ Attitude of dentists about COVID-19 } & $\mathrm{n}$ & p-value \\
\hline \multirow{4}{*}{$\begin{array}{c}\text { 8-I will not do my clinical duties } \\
\text { in a hospital without a clear } \\
\text { COVID-19 infection control } \\
\text { isolation policy }\end{array}$} & Strongly agree & $256^{\mathrm{A}}$ & $67.0 \%$ \\
\cline { 2 - 4 } & Agree & $85^{\mathrm{B}}$ & $22.3 \%$ \\
\cline { 2 - 4 } & Neutral & $23^{\mathrm{C}}$ & $6.0 \%$ \\
\cline { 2 - 4 } & Disagree & $14^{\mathrm{C}}$ & $3.7 \%$ \\
\hline \multirow{3}{*}{$\begin{array}{c}\text { 9- The governmental institutions } \\
\text { can control the pandemic }\end{array}$} & Strongly disagree & $4^{\mathrm{D}}$ & $1.0 \%$ \\
\cline { 2 - 4 } & Strongly agree & $33^{\mathrm{A}}$ & $8.6 \%$ \\
\cline { 2 - 4 } & Agree & $80^{\mathrm{B}}$ & $20.9 \%$ \\
\cline { 2 - 4 } & Neutral & $140^{\mathrm{C}}$ & $36.6 \%$ \\
\cline { 2 - 4 } & Disagree & $89^{\mathrm{B}}$ & $23.3 \%$ \\
\hline
\end{tabular}

Different superscript letters indicate a statistically significant difference within the same question*; significant (p $\leq 0.05) n s$; non-significant $(p>0.05)$

Table (IX): Frequencies (n) and percentages (\%) of responses to practice questions

\begin{tabular}{|c|c|c|c|c|}
\hline \multicolumn{2}{|c|}{ Practice of dentists about COVID-19 } & \multirow{2}{*}{$\frac{\mathrm{n}}{189}$} & \multirow{2}{*}{$\frac{\%}{49.48 \%}$} & $p$-value \\
\hline \multirow{3}{*}{$\begin{array}{l}\text { 1-Are you currently taking every } \\
\text { patient's body temperature before } \\
\text { performing dental treatment? }\end{array}$} & Yes & & & \multirow{3}{*}{$0.838 n s$} \\
\hline & No & 193 & $50.52 \%$ & \\
\hline & I don't know & 0 & $0 \%$ & \\
\hline \multirow{3}{*}{$\begin{array}{l}\text { 2-Are you deferring dental treatment } \\
\text { of patients showing suspicious } \\
\text { symptoms? }\end{array}$} & Yes & 320 & $83.77 \%$ & \multirow{3}{*}{$<0.001 *$} \\
\hline & No & 62 & $16.23 \%$ & \\
\hline & I don't know & 0 & $0 \%$ & \\
\hline \multirow{3}{*}{$\begin{array}{l}\text { 3-Do you think surgical mask is } \\
\text { enough to prevent cross-infection of } \\
\text { COVID-19? }\end{array}$} & Yes & $35^{\mathrm{A}}$ & $9.16 \%$ & \multirow{3}{*}{$<0.001 *$} \\
\hline & No & $308^{\mathrm{B}}$ & $80.63 \%$ & \\
\hline & I don't know & $39^{\mathrm{A}}$ & $10.21 \%$ & \\
\hline \multirow{3}{*}{$\begin{array}{l}\text { 4-Do you think N-90 mask should be } \\
\text { routinely worn in dental practice } \\
\text { due to the current outbreak? }\end{array}$} & Yes & $323^{\mathrm{A}}$ & $84.55 \%$ & \multirow{3}{*}{$<0.001 *$} \\
\hline & No & $30^{\mathrm{B}}$ & $7.85 \%$ & \\
\hline & I don't know & $29^{\mathrm{B}}$ & $7.59 \%$ & \\
\hline \multirow{3}{*}{$\begin{array}{l}\text { 5-Have you ever worn an N-90 mask } \\
\text { while treating a patient in your den- } \\
\text { tal practice? }\end{array}$} & Yes & 172 & $45.03 \%$ & \multirow{3}{*}{$0.052 n s$} \\
\hline & No & 210 & $54.97 \%$ & \\
\hline & I don't know & 0 & $0 \%$ & \\
\hline \multirow{3}{*}{$\begin{array}{l}\text { 6-Do you routinely follow universal } \\
\text { precautions of infection control for } \\
\text { every patient? }\end{array}$} & Yes & 358 & $93.72 \%$ & \multirow{3}{*}{$0.145 n s$} \\
\hline & No & 24 & $6.28 \%$ & \\
\hline & I don't know & 0 & $0 \%$ & \\
\hline \multirow{3}{*}{$\begin{array}{l}\text { 7-Do you use rubber dam isolation for } \\
\text { every patient? }\end{array}$} & Yes & 147 & $38.48 \%$ & \multirow{3}{*}{$<0.001 *$} \\
\hline & No & 235 & $61.52 \%$ & \\
\hline & I don't know & 0 & $0 \%$ & \\
\hline \multirow{3}{*}{$\begin{array}{l}\text { 8-Do you use high-volume suction in } \\
\text { your practice for every patient? }\end{array}$} & Yes & 249 & $65.18 \%$ & \multirow{3}{*}{$<0.001 *$} \\
\hline & No & 133 & $34.82 \%$ & \\
\hline & I don't know & 0 & $0 \%$ & \\
\hline
\end{tabular}




\begin{tabular}{|c|c|c|c|c|}
\hline \multirow{3}{*}{$\begin{array}{l}\text { 9- Do you ask every patient to rinse } \\
\text { his/her mouth with anti-bacterial } \\
\text { mouthwash before treatment? }\end{array}$} & Yes & 155 & $40.58 \%$ & \multirow{3}{*}{$<0.001 *$} \\
\hline & No & 227 & $59.42 \%$ & \\
\hline & I don't know & 0 & $0 \%$ & \\
\hline \multirow{3}{*}{$\begin{array}{l}\text { 10- Do you wash hands with soap and } \\
\text { water/use sanitizer before and after } \\
\text { treatment of every patient? }\end{array}$} & Yes & 370 & $96.86 \%$ & \multirow{3}{*}{$<0.001 *$} \\
\hline & No & 12 & $3.14 \%$ & \\
\hline & I don't know & 0 & $0 \%$ & \\
\hline \multirow{3}{*}{$\begin{array}{l}\text { 11- Are you aware of which authority } \\
\text { to contact if you come across a } \\
\text { patient with suspected COVID-19 } \\
\text { infection? }\end{array}$} & Yes & 291 & $76.18 \%$ & \multirow{3}{*}{$<0.001 *$} \\
\hline & No & 91 & $23.82 \%$ & \\
\hline & I don't know & 0 & $0 \%$ & \\
\hline
\end{tabular}

Different superscript letters indicate a statistically significant difference within the same question*; significant (p $\leq 0.05) n s$; non-significant $(p>0.05)$

\section{DISCUSSION}

Currently, COVID-19 is considered a major public concern. The increasing count of infected cases raised tensions for everyone, especially HCWs and patients. Dental care units are considered high zones of infection transmission, so routine dental practices were suspended by the Egyptian general authorities and restricted to emergency services. ${ }^{26]}$

Dentists should be well educated about the new public crises for the welfare of their health and the health of their patients. For these reasons, the assessment of knowledge and perceptions of dentists towards the COVID-19 pandemic is of prime importance. ${ }^{[27]}$

The Electronic Questionnaire was used in the study, as it is satisfying the new pandemic lifestyle (partial curfew/social distancing) and offers a wide range of accessibility to dentists through social media. ${ }^{[28]}$

In the current study, the response rate was $0.0457 \%$. This was far beyond what was previously reported by Srivastava et al., ${ }^{[29]}(79.5 \%)$ whose study was designed to detect KAP of DHCWs regarding the COVID-19 pandemic across five geographical regions of Saudi Arabia and Kamate et al., [30] (83.8\%) who assessed KAP of dentists regarding the COVID-19 pandemic on a multinational basis
(America, Asia, Europe, Africa, Australia, and Antarctica). The low response rate reported by the Egyptian dentists may be attributed to the nature of the groups of social media to which the questionnaire was sent where the very high frequency of variable notifications per day may affect the relative time for detecting all notifications, some members of the social media groups may not be user friendly to the media itself or to response to electronic forms or the lack of time expressed by many dentists.

The first section of the questionnaire is concerned with the background data. Significantly, higher percentages of respondents were above 30 years old, females, specialists, and working in both public and private sectors. These agree, to some extent, to what was reported by Khader et al., $2020^{[4]}$; where the mean age of their study population was 32.9 years, mostly females, their work sectors included university clinics, private, and public sectors equally, and 30.4\%, and Ahmad et al., $2020^{[1]}$ who studied dentists` practice modifications concerning COVID-19 outbreak in different countries and found that most participants were females and their age range was between 20 and 40 years, however, most were general dentists and practiced at private sectors.

Also, a significantly higher percentage of respondents thought that they have sufficient 
COVID-19 knowledge. This goes in agreement with Bhagavathula et al., $2020^{[31]}$ among HCWs globally during the first week of March 2020.

Regarding the COVID-19 knowledge, the majority of the respondents $(80.9 \%)$ chose to depend on combined sources (WHO, MOHP, Mass, and Social media). This was the same situation in Bhagavathula et al., ${ }^{[31]}$ study. However, Nasser et al., $2020{ }^{[33]}$ reported that $(73.7 \%)$ got the information from the WHO, (52.8\%) from the Ministry of Public Health, and (44.7\%) from Television.

The second section is concerned with the knowledge of dentists about COVID-19, a significantly higher percentage of respondents were sure of the causative microorganism (95.0\%), fatality $(99.7 \%)$, ease of transmission (96.6\%), and prevention of transmission by hand washing $(97.9 \%)$. These agreed with Srivastava et al., ${ }^{[29]}$ who reported that most dental health caregivers in Saudi Arabia showed adequate knowledge of the incubation period (95.3\%) and symptoms (97.5\%) and the work of Kamate et al., $2020{ }^{[30]}$ where significant differences were recorded regarding questions concerned with the affected system and fatality.

Regarding the attitude of dentists about COVID-19 (3 ${ }^{\text {rd }}$ Section), a significantly higher percentage of respondents, strongly disagreed that COVID-19 was not a serious issue (56.0\%), disagreed that symptoms often resolve with time and don't require any special treatment $(33.0 \%)$, and agreed that transmission can be prevented by using the WHO standard isolation precautions $(43.5 \%)$. These were in agreement with de Miranda Candeiro et al., $2020^{[34]}$ where Brazilian endodontists affirmed that COVID-19 can be transmitted during dental procedures, and $76.53 \%$ reported that conventional personal protective equipment is insufficient to prevent COVID-19 transmission.

Meanwhile, Khader et al., $2020{ }^{[4]}$ stated that $36.7 \%$ of dentists believed that COVID-19 is not a serious issue, $55.2 \%$ of dentists reported that symptoms often resolve with time, and most agreed that COVID-19 transmission can be prevented by using the WHO standard isolation precautions. This perception about the disease self-resolved (COVID-19 is not a serious issue and often resolve with time ) could have explained the perception about its threat where no local cases in Jordan were detected at the time of the study.

The relatively low percentage of agreement that transmission could be prevented by using the WHO standard isolation precautions evident in the current study may be attributed to the aggressive nature, rapid transmission, and high rate of fatality of COVID-19. In addition, the fear and anxiety of dentists are powerful emotions that may be associated with the overwhelming reports on the COVID-19 pandemic by social, electronic, and print media. ${ }^{[34]}$

A significantly higher percentage of respondents felt neutral regarding the ability of the governmental institutions of controlling the pandemic (36.6\%). This was not the case in the study done by Assad et al., $2019^{[21]}$, where almost $92 \%$ of students felt that the government could be able to control any emerging MERS epidemic. This may be attributed to the different nature and management of the two viruses even though they belong to the same family.

Also, a significantly higher percentage of dentists refused to work in a hospital where COVID-19 cases were treated, because of the possibility of disease transmission through asymptomatic infected medical personnel during the incubation period of the disease. ${ }^{[35]}$

In addition, it was found that $89.3 \%$ of respondents strongly agreed to the necessity of educating people about COVID-19, 91.1\% of HCWs must acknowledge themselves with all the virus information, and that $67.0 \%$ would not work in a hospital without a clear COVID-19 infection control isolation policy. This was in agreement with 
Khader et al., $2020{ }^{[4]}$ who reported that the dentist plays a significant role in teaching others about the virus.

The fourth section of the questionnaire was about the practice of dentists during the pandemic. Surprisingly, there was no significant difference between answers to the questions regarding taking body temperature before dental treatment, wearing an N-95 mask, and following universal precautions of infection control for every patient. This was opposite to the results of Ahmed et al., ${ }^{[1]}$ where $81 \%$ recorded every patient's body temperature, $90 \%$ reported not wearing $\mathrm{N}-95$ masks, and $89 \%$ recommended routine universal infection control precautions.

A significantly higher percentage of respondents deferred dental treatment of suspicious cases (83.77\%) as recommended by the Egyptian MOHP, which adopts the WHO protocol. This was in agreement with Tokuç and Coşkunses, 2020 [36] where the majority of Turkish dentists deferred any elective treatment, and de Miranda Candei et al., $2020^{[35]}$ where Brazilian endodontists confirmed treatment of urgent cases only.

Also, a significantly higher percentage of respondents did not think surgical mask was sufficient to prevent cross-infection (80.63\%), favored the routine wear of N-95 masks $(84.55 \%)$, did not use rubber dam for isolation $(61.52 \%)$, used high volume section $(65.18 \%)$, did not instruct patients to use mouthwash $(59.42 \%)$, washed their hands with soap and sanitizer before and after treatment $(96.86 \%)$, and were aware of suspected cases referral authority (76.18\%), where most of the Egyptian dentists followed the Egyptian Ministry of Health and Population (MOHP) recommendations which follow the WHO general precaution measures except for the use of rubber dam.

These results were comparable to the results of Ahmed et al., ${ }^{[1]}$ where $85 \%$ believed that a surgical mask is not enough to prevent cross-infection, $84 \%$ favored the use of N-95 masks, $84 \%$ did not use a rubber dam, $76 \%$ used high-volume suction for every patient, $74 \%$ did not ask patients to rinse with mouthwash before treatment, $95 \%$ practiced hand washing before and after treatment, while $80 \%$ were aware of suspected cases referral authority, and also to the findings of Tokuç and Coşkunses, ${ }^{[36]}$ where the majority of Turkish dentists followed strictly the WHO precaution measures.

Despite the current findings, this survey had some limitations including the possibility of recall bias where the collected data were self-reported and dependent on the respondents' recall ability and honesty. Also, sample selection bias could not be avoided since the electronic survey does not obey the principles of sample checking of the participants. This translates that those who were active on social media at the time of data collection were the only ones that had the chance to participate in the survey.

Among the limitations of this study are that the instructions to how the questionnaire should be answered were given in a written form and the participants were not allowed to inquire about any of the included questions which are clearer through life interactions.

\section{CONCLUSION}

- The majority of Egyptian dentists were aware of the COVID-19 virus, mode of transmission, and infection control precautions in the dental clinic.

- The Egyptian majority of dentists showed a positive attitude towards the importance of education of HCWs about COVID-19 and stressed not working in hospitals treating COVID-19 or where standard infection control precautions were not followed.

- Dentists had limited comprehension of the extra precautionary measures that protect the dental personnel and patients from COVID-19.

- A significantly higher percentage of respondents deferred dental treatment of suspicious children. 


\section{QUESTIONNAIRE}

We are studying the knowledge, attitude and practice of the dentists towards Coronavirus disease (COVID-19) which is an infectious disease caused by a newly discovered coronavirus,

If you have any comments regarding this survey, you are welcome to contact us via e-mail. Your answers will be confidential, we appreciate your participation that will help to facilitate outbreak management of COVID-19 in Egypt and to increasing dentists' role in detecting and reporting Coronavirus cases at this critical moment.

\section{Consent form:}

The aim of this study is to assess the knowledge, attitude and practice of the dentists towards Coronavirus disease (COVID-19). This is a research project being conducted in the Faculty of Dentistry, Cairo University.

Your participation in this survey is voluntary. You may choose to participate, kindly answer the following questions to the best of your ability. If you decide not to participate in this research survey, you may withdraw at any time.

\section{Electronic Consent:}

Please select your choice below. Clicking on the 'agree' button below indicates that, you have read the information above, and you voluntarily agree to participate.

\section{Would you like to participate in this survey?}
a) I agree to participate
b) I disagree.

\section{I-Demographics and professional background of dentists participating in the study:}
1- Age:
$\begin{array}{ll}\text { a) }<30 & \text { b) }>30\end{array}$
2- Gender:
a) Male $\quad$ b) Female
3- Specialty:
a) Specialist
b) Not a specialist
4- Nature of practice:
a) Private sector
b) Governmental sector (MOHP \& University)
c) Both

5- Do you have other Healthcare provider (s) in the family?

a) Yes

b) No

6- Do you have any relatives or friends who suffered from COVID 19?

a) Yes

b) No

7- From your point of view, do you have sufficient knowledge about COVID 19?

a) Yes

b) No

8- What is your source of knowledge about COVID 19?

a- WHO website

b- MOHP website

c- TV or radio

d- Friends/ peers

e- Posters and brochures

f- Social media

g- More than one source of data

II- Knowledge of dentists about COVID 19:

\begin{tabular}{|c|c|c|c|}
\hline & Yes & No & I don't know \\
\hline 1- Is COVID 19 caused by coronavirus? & & & \\
\hline 2- Could COVID 19 be fatal in some cases? & & & \\
\hline 3- Could COVID 19 be transmitted easily from person to person? & & & \\
\hline 4-Do washing hands with soap and water can help in the prevention of disease transmission? & & & \\
\hline
\end{tabular}


III- Attitude of dentists about COVID 19:

\begin{tabular}{|c|c|c|c|c|c|}
\hline & $\begin{array}{l}\text { Strongly } \\
\text { agree }\end{array}$ & Agree & Neutral & Disagree & $\begin{array}{l}\text { Strongly } \\
\text { disagree }\end{array}$ \\
\hline $\begin{array}{l}\text { 1- I believe COVID } 19 \text { is not currently a serious public } \\
\text { health issue }\end{array}$ & & & & & \\
\hline $\begin{array}{l}\text { 2- COVID } 19 \text { symptoms often resolve with time and } \\
\text { do not require any special treatment }\end{array}$ & & & & & \\
\hline $\begin{array}{l}\text { 3- Educating people about COVID } 19 \text { is important to } \\
\text { prevent the spread of the disease }\end{array}$ & & & & & \\
\hline $\begin{array}{l}\text { 4- You worry about one of your family members can } \\
\text { get the infection }\end{array}$ & & & & & \\
\hline $\begin{array}{l}\text { 5- Healthcare workers must acknowledge themselves } \\
\text { with all the information about the virus }\end{array}$ & & & & & \\
\hline $\begin{array}{l}\text { 6- Transmission of COVID } 19 \text { can be prevented by } \\
\text { using standard isolation precautions recommended } \\
\text { by the CDC, and WHO. }\end{array}$ & & & & & \\
\hline $\begin{array}{l}\text { 7- I will not do my clinical duties in a hospital where } \\
\text { COVID } 19 \text { patients are treated }\end{array}$ & & & & & \\
\hline $\begin{array}{l}8 \text { - I will not do my clinical duties in a hospital without } \\
\text { a clear COVID } 19 \text { infection control isolation policy }\end{array}$ & & & & & \\
\hline $\begin{array}{l}\text { 9- The governmental institutions can control the } \\
\text { pandemic }\end{array}$ & & & & & \\
\hline
\end{tabular}

IV- Practice of dentists about COVID 19:

\begin{tabular}{|l|l|l|l|}
\hline 1- $\begin{array}{l}\text { Are you currently taking every patient's body temperature before performing dental } \\
\text { treatment? }\end{array}$ & Yes & I don't know \\
\hline 2- Are you deferring dental treatment of patients showing suspicious symptoms? & & & \\
\hline 3- Do you think surgical mask is enough to prevent cross-infection of COVID 19? & & & \\
\hline 4- Do you think N-95 mask should be routinely worn in dental practice due to the current & & & \\
\hline 5- Have you ever worn an N-95 mask while treating a patient in your dental practice? & & & \\
\hline 6- Do you routinely follow universal precautions of infection control for every patient? & & & \\
\hline 7- Do you use rubber dam isolation for every patient? & & & \\
\hline 8- Do you use high-volume suction in your practice for every patient? & & \\
\hline $\begin{array}{l}\text { 9- Do you ask every patient to rinse his/her mouth with anti-bacterial mouthwash before } \\
\text { treatment? }\end{array}$ & & & \\
\hline 10- Do you wash hands with soap and water/use sanitizer before and after treatment of every & & & \\
\hline 11- Are you aware of which authority to contact if you come across a patient with suspected & & & \\
\hline
\end{tabular}




\section{RECOMMENDATIONS}

The authors recommend that dental associations should ensure that dentists are well informed and trained about the nature of the virus, its mode of transmission, specific infection control precautions, and the best Up-to-date practices regarding the $\mathrm{CO}$ VID-19 pandemic.

\section{REFERENCES}

1. Ahmed M A, Jouhar R, Ahmed N, Adnan S, Aftab M, Zafar M S and Khurshid Z. Fear and Practice Modifications among Dentists to Combat Novel Coronavirus Disease (COVID-19) Outbreak. Int. J. Environ. Res Public Health. 2020; 17 (2821): 1-11 doi: 10.3390/ijerph17082821

2. Gralinski, L E, Menachery V D. Return of the coronavirus: 2019-nCoV. Viruses. 2020; 12(2):135-43. doi: 10.3390/ v12020135

3. Neelam Das. "Understanding of Novel Coronavirus Disease 2019 (2019-nCoV): Newest and Biggest Emerging Threat in the Dental Practice”. EC Dental Science. 2020; 19 (10):20-40.

4. Khader Y, Al Nsour M, Al-Batayneh O B, Saadeh R, Bashier H, Alfaqih M, Al-Azzam S, and AlShurman B A. Dentists' Awareness, Perception, and Attitude Regarding COVID-19 and Infection Control: Cross-Sectional Study Among Jordanian Dentists. JMIR Public Health Surveill. 2020; 6(2): e18798.

5. Zu, Z.Y.; Jiang, M.D.; Xu, P.P.; Chen, W.; Ni, Q.Q.; Lu, G.M.; Zhang, L.J. Coronavirus Disease 2019 (COVID-19): A Perspective from China. Radiology. 2020; 296(2): E15E25. doi: 10.1148/radiol.2020200490

6. Khurshid, Z.; Asiri, F.Y.I.; Wadaani, H. Al Human Saliva: Non-Invasive Fluid for Detecting Novel Coronavirus (2019nCoV). Int J Environ Res Public Health 2020; 17, 2225.

7. Peng, X.; Xu, X.; Li, Y.; Cheng, L.; Zhou, X.; Ren, B. Transmission routes of 2019-nCoV and controls in dental practice. Int J Oral Sci. 2020; 12:1-6.

8. Spicciarelli V, Marruganti C, Viviano M, Baldini N, Franciosi G, Tortoriello M, Grandini S. Prevention and safety in the dental office after Novel Human Coronavirus outbreak: unresolved questions and future directions. J Osseointegr. 2020; 12(2):145-53. doi 10.23805/JO.2020.12.01.11
9. Gupta P, Bhagyalakshmi A, Mehta P. COVID-19: a dental perspective. Int J Community Med Public Health. 2020;7 (5):1994-7.

10. Guan, W.; Ni, Z.; Hu, Y.; Liang, W.; Ou, C.; He, J.; Liu, L.; Shan, H.; Lei, C.; Hui, D.S.C.; et al. Clinical Characteristics of Coronavirus Disease 2019 in China. N Engl J Med. 2020; 382:1708-20. doi: 10.1056/NEJMoa2002032

11. Checchi V, Bellini P, Bencivenni D, Consolo U. COVID-19 dentistry-related aspects: a literature overview. Int Dent J. 2020; FDI World Dental Federation, 1-7. https:// doi.org/10.1111/IDJ.12601.

12. Gaffar B O, El Tantawi M, Al-Ansari A A, AlAgl A S, Faraz A. Farooqi F A, Almas K M. Knowledge and practices of dentists regarding MERS-CoV. A cross-sectional survey in Saudi Arabia. Saudi Med J. 2019; 40 (7): 714-20.

13. Gurzawska-Comis K, Becker K, Brunello G, Gurzawska A, and Schwarz F. Recommendations for Dental Care during COVID-19 Pandemic. J Clin Med. 2020; 9(6), 183348; https://doi.org/10.3390/jcm9061833

14. Meng L, Hua F, Bian Z. Coronavirus disease 2019 (COVID-19): emerging and future challenges for dental and oral medicine. J Dent Res 2020; 99(5): 481-7. [http://dx.doi. org/10.1177/0022034520914246] [PMID: 32162995]

15. Barabari P and Moharamzadeh K. Novel Coronavirus (COVID-19) and Dentistry-A Comprehensive Review of Literature. Dent J. 2020; 8(2): 53- 61; https://doi.org/10.3390/ dj8020053

16. World Health Organization. 2020. Mar 13, Clinical management of severe acute respiratory infection when $\mathrm{CO}$ VID-19 is suspected https://tinyurl.com/s23yv4p.

17. The American Dental Association. 2020. Mar 27, Coronavirus frequently asked questions. https://success.ada.org/ en/practice-management/patients/coronavirus-frequentlyasked-questions.

18. Rajeh M. COVID-19 and Infection Control in Dental Clinics; Assessment of Public Knowledge, Attitudes and Practices in Several Regions of Saudi Arabia. Open Dent. J. 2020; 14: 489-97. DOI: 10.2174/1874210602014010489

19. Randa Abd Al Gawad and Rasha Hanafy. The impact of COVID-19 Pandemic on Utilization of Pediatric Dental Care of Egyptian Children: A Retrospective study. EDJ, 2021; 67 (1): 131-7.

20. Spagnuolo G, De Vito D, Rengo S, and Tatullo M. COVID-19 Outbreak: An Overview on Dentistry. Int. J. 
Environ. Res Public Health. 2020; 17(6): 2094- 7; https:// doi.org/10.3390/ijerph17062094

21. Asaad A M, El-Sokkary R H, Aedh A I, Alzamanan M A A, and Fatma Omar Khalil F O. Exploring Knowledge and Attitude toward Middle East Respiratory Syndrome-Coronavirus (MERS-CoV) Among University Health Colleges' Students, Saudi Arabia: A Cross- Sectional Study. Am J Infect Dis. 2019; 1-8. doi: 10.3844/ajidsp.2019

22. Elrggal ME, Karami NA, Rafea B, Alahmadi L, Al Shehri A, Alamoudi R, Koshak H, Alkahtani S, Cheema E. Evaluation of preparedness of healthcare student volunteers against Middle East respiratory syndrome coronavirus (MERS-CoV) in Makkah, Saudi Arabia: a cross-sectional study. J Public Health: From Theory to Practice. 2018; 26:607-12.https://doi.org/10.1007/s10389-018-0917-5

23. CDC, 2020. Centers for Disease Control and Prevention, Interim Guidance on Management of Corona Virus Disease 2019 (COVID-19) in Correctional and Detention Facilities. Last Updated Oct. 21, 2020. https://www.cdc.gov

24. ADA,2020. American Dental Association 2020, Guidance on Continuing to Practice Ethically during COVID-19, 1-4. Last Updated: October 28, 2020.

25. 25-Dean, A. G., et al. "Epi Info ${ }^{\mathrm{TM}}$, a database and statistics program for public health professionals." CDC, Atlnta, GA, USA. 2011. https://stacks.cdc.gov/view/ cdc/23208/cdc_23208_DS1.pdf?download-documentsubmit=Download

26. 26- World Health Organization. Infection prevention and control during health care when novel coronavirus $(\mathrm{nCoV})$ infection is suspected: interim guidance, January 2020. Available online: https://www.who.int/publicationsdetail/infectionprevention-and-control-during-healthcare-when-novel-coronavirus-(ncov)-infection-issuspected-20200125 (Retrieved on September 2020).

27. World health organization. Emerging respiratory viruses, including COVID-19: methods for detection, prevention, response, and control. Available online: https://openwho.org/ courses/introduction-to-ncov (Retrieved on September 2020).

28. Hoffman SJ, Silverberg SL. Delays in Global Disease Outbreak Responses: Lessons from H1N1, Ebola, and Zika.
Am J Public Health. 2018; 108 (3):329-33. doi: 10.2105/ AJPH.2017.304245.

29. Srivastava KC, Shrivastava D, Sghaireen MG, Alsharari AF, Alduraywish A A, Al-Johani K, Alam MK, Khader Y, Alzarea BK. Knowledge, attitudes and practices regarding COVID-19 among dental health care professionals: a cross-sectional study in Saudi Arabia. J of Int Med Res; 2020; 48(12) 1-19.

30. Kamate SK, Sharma S, Thakar S, Srivastava D, Sengupta K, Hadi AJ, Chaudhary A, Joshi R, Dhanker K. Assessing Knowledge, Attitudes and Practices of dental practitioners regarding the COVID-19 pandemic: A multinational study. Dent Med Probl.2020; 57(1):11-17. doi:10.17219/ dmp/119743

31. Bhagavathula AS, Aldhaleei WA, Rahmani J, Mahabadi MA, Bandari DK. Novel Coronavirus (COVID-19) Knowledge and Perceptions: A Survey of Healthcare Workers. JMIR Public Health Surveill. 2020; 6(2): e19160. doi: $10.2196 / 19160$.

32. Nasser z, Fares Y, Daoud R, Abou-Abbas L. Assessment of knowledge and practice of dentists towards Coronavirus Disease (COVID-19): a cross-sectional survey from Lebanon. BMC Oral Health. 2020; 20:281:2-9.

33. de Miranda Candeiro GTM, Gavini G, Vivan RR, Carvalho BMDF, Duarte MAH, Feijão CP, Fernandes APG, Vieira-meyer, Knowledge about Coronavirus disease 19 (COVID-19) and its professional repercussions among Brazilian endodontists. Braz Oral Res; 2020; 34: e117.

34. Ahmed MA, Jouhar A, Ahmed N, Adnan S, Aftab M, Zafar MS, Khurshid Z. Fear and Practice Modifications among Dentists to Combat Novel Coronavirus Disease (COVID-19) Outbreak. Int J Environ Res. Public Health 2020, 17:1-11.

35. Meng L, Hua F, Bian Z. Coronavirus Disease 2019 (COVID-19): Emerging and Future Challenges for Dental and Oral Medicine. J Dent Res. 2020 ;99(5):481-7. doi: 10.1177/0022034520914246. PMID: 32162995.

36. Tokuç B and Coşkunses FM Knowledge, attitude and practice of dentists in Coronavirus disease 2019 pandemic in Turkey. Eur Oral Res. 2020; 54(2): 86-91. 